EGU21-9250

EGU General Assembly 2021

(c) Author(s) 2021. This work is distributed under

the Creative Commons Attribution 4.0 License.

\title{
Active thrusting and glacial controls recorded by stratigraphic unconformities in a Quaternary foreland basin (Po basin, Northern Italy)
}

Chiara Zuffetti and Riccardo Bersezio

University of Milan, Department of Earth Sciences, Milano, Italy (chiara.zuffetti@unimi.it)

In active foreland basins, stratigraphic unconformities develop on the flanks and crests of the uplifting thrust-related structures and correspond to correlative conformities in the adjacent depocenters. The geometrical, morphological, stratigraphic, sedimentological, and petrographic attributes of unconformities and associated sediments are highly variable from the uplifting to the subsiding basin sectors. In Quaternary continental foreland basins, landscape evolution, sedimentation, and the nature of the geological boundaries are controlled by the competing turnovers of climate (i.e. glacial advances and retreats) and tectonics (i.e. steady-state uplift/subsidence vs. unsteady deformation increments).

In order to recognize the fingerprints of tectonic and climatic factors on the nature of the stratigraphic unconformities, we studied the Pleistocene shallow marine (Calabrian) to alluvial and glacio-fluvial sediments (Calabrian-Latest Pleistocene) associated to the active external arc of the NApennine thrusts in the Quaternary Po basin of Lombardy (N-Italy).

A set of intra-basin reliefs corresponding to ramp-folds was the key-site to describe the nature and attributes of the exposed Pleistocene unconformities and stratigraphy. We integrated differentscale geological, sedimentological, stratigraphic, geo-pedological, geomorphological, and structural field surveys, constrained by C14 and OSL age determinations, to down-trace the stratigraphic boundaries to the subsurface and to assist correlation of borehole logs and geophysical images. The surface facies associations of the stratigraphic units were compared to the litho-textural associations of their subsurface equivalents to draw the best fitting surface-subsurface model, which was constrained to the geological evolution and chronostratigraphy. A hierarchic 3D geological model was computed by the potential field method, which includes the 4D attributes of the stratigraphic boundaries and unconformities organized into three hierarchic orders. Among them, five Quaternary high-rank, and seven intermediate-rank unconformities were recognized.

The high-rank unconformities (Gelasian, intra-Calabrian, Early-Middle Pleistocene, Late Pleistocene and Latest Pleistocene-Holocene unconformities) are erosional, angular (high angle), composite, diachronous surfaces. They originated in front of and above the uplifting ramp-folds, where the discrete, polyphase, and unsteady propagation stages of the blind outermost Apennines arc directly controlled sedimentation, erosion, and accommodation patterns. The intermediate- and low-rank stratigraphic boundaries are either: (i) stratigraphic surfaces of erosion and deposition, 
occasionally with low-angle unconformity; (ii) stratigraphic surfaces of aggradation (covered by late Pleistocene loess units at places); (iii) morphological surfaces of stabilization marked by (paleo-) soils. These attributes and the 3D relations with the high-rank unconformities show that these surfaces formed during steady uplift/subsidence increments and/or at times or sites of tectonic quiescence. In these cases, the development of erosion surfaces, facies and provenance changes are not associated to tectonic-induced angles, wedging or fanning of sedimentary units. Chronological constraints link these changes to the regional advances and retreats of the Pleistocene alpine glaciers, suggesting that the intermediate-rank surfaces are mostly dependent on the major climate changes, while the low-rank ones relate to depositional unsteadiness, either autocyclic or short-term allocyclic. 